\title{
Legers yrkesetiske dilemmaer
}

I løpet av et legeliv vil de fleste oppleve etiske og moralske dilemmaer som det aldri vil finnes enkle eller allmenngyldige svar på. Ulike former for etiske grunnprinsipper, eksempelvis pliktetikk versus nytteetikk, vil kunne gi forskjellige svar (1). Dilemmaer knyttet til livets begynnelse og slutt er blant de vanskeligste vi blir stilt overfor. Andre er prioritering mellom ulike oppgaver og behandlinger, mellom ulike pasienter og pasientgrupper samt ressursbruk generelt.

For at slike etiske problemstillinger skal komme frem i lyset og ikke leve sitt eget liv i det skjulte, må det herske en kultur for åpenhet både $\mathrm{i}$ helsetjenesten og $\mathrm{i}$ samfunnet ellers. Undersøkelsen til Førde \& Aasland publisert i dette nummer av Tidsskriftet (2) viser, ikke overraskende, at leger opplever betydelige etiske utfordringer og stress knyttet til arbeidet. Hvordan leger opplever den faglige ytringsfriheten og i hvilken grad det er åpenhet for kritiske røster i helsetjenesten, blir også belyst.

Et av artikkelens overraskende funn er at leger synes de opplever mindre moralsk stress og mer faglig ytringsfrihet i 2010 enn i 2004. Forfatternes tolkning er at det lavere stressnivået knyttet til etiske konflikter skyldes bedre måter å håndtere stressituasjoner på, eller at konsekvensene av omorganiseringene i helsevesenet oppleves som mindre truende enn de var i 2004 da sykehusreformen var ny. Men også faglig og etisk resignasjon kan ligge bak.

Det er likevel usikkert om man ville ha fått samme resultat dersom man hadde gjentatt undersøkelsen i dag. Helsetjenesten har vært igjennom flere tunge prosesser siden 2010, og konfliktnivå og kritikk fra fagmiljøer har økt. Jeg vil nevne prosessen rundt sykehussammenslåingen i Oslo, som har vært alt annet enn smertefri, noen vil si katastrofal (3), og som har splittet solide fagmiljøer, møysommelig bygd opp over mange år. Charlotte Haug ytret i en leder i Tidsskriftet i nr. 18/2010 bekymring for at de ansatte ved Oslo universitetssykehus ikke torde å uttale seg offentlig (4). Hun opplevde å få massiv støtte per e-post og telefon (5), men det var svært få som ønsket å gå offentlig ut med sin kritikk.

I en undersøkelse utført av NRK i desember 2011 svarte nesten $58 \%$ av sykepleierne og $66 \%$ av legene ved Oslo universitetssykehus at de var helt eller delvis enig i påstanden om at det er en fryktkultur der (6). Også sykehusmiljøene selv har gitt slike signaler (7). Ved Universitetssykehuset Nord-Norge har tillitsvalgte hevdet at det blir lagt lokk på betydelige uoverensstemmelser mellom den administrative ledelsen og de praktiserende helsearbeiderne nedover i systemet. Vi har vært vitne til et styringssystem som med sin mål- og resultatstyring har medført økte mengder papirarbeid og $ø$ kt byråkratisk kontroll. Det hevdes stadig oftere at foretaksmodellen for sykehustjenesten har ført til at politikerne har overlatt viktige helsepolitiske prioriteringer til administrasjon og byråkrati. Regjeringens opprinnelige forslag til revidert fastlegeforskrift (8) er et godt eksempel på at problemene også gjelder primærhelsetjenesten. Den fikk fastlegene til å samle seg i protest i form av Fastlegeaksjonen (9). Mye av protesten handlet om at fastlegene ikke lenger skulle kunne prioritere oppgaver og dilemmaer på selvstendig faglig grunnlag, men at enkelte mål som bl.a. responstid på telefon og ventetid på time skulle være forskriftsfestet. Samlet sett viser situasjonen både i primær- og spesialisthelsetjenesten at vi har mistet viktig demokratisk kontroll av helsetjenesten. Dette er noe av det Helsetjenesteaksjonen (10) nå forsøker å tydeliggjøre.
Reidun Førde har i en kronikk i Dagens Medisin kommet med klar advarsel til legene om ikke å la seg kue til å bli «lydige funksjonærer» (11). Det er all grunn til å gjenta denne advarselen. En tilpasning til systemet på kort sikt kan synes hensiktsmessig og vil i seg selv dempe legenes opplevelse av moralsk stress. På lengre sikt kan imidlertid en slik yrkesmessig resignasjon føre til svekket moralsk sensitivitet, noe som vil være et tap for både faget og pasientene. Førde \& Aasland har i artikkelen (2) vært inne på det samme i sin tolkning.

Leger har i tillegg til ansvaret overfor den enkelte pasient også et samfunnsansvar og moralsk plikt til å gi tydelig beskjed om feil og mangler i helsetjenesten. Dette gjelder både ved tildeling og fordeling av ressurser og eventuelle konsekvenser dette kan få for pasienter, og observert svikt i klinisk praksis og i systemet. Legene må være forberedt på å bli møtt med beskyldninger om å mele sin egen kake og å bruke pasienter for å fremme faglige særinteresser på bekostning av andre grupper, noe som også kan være en berettiget kritikk. Andre ganger kan den som varsler bli møtt med beskyldninger om illojalitet. Men legens lojalitet må alltid først og fremst ligge hos pasienten.

Det har vært et viktig mål å verne om varslere, og dette er også blitt nedfelt i lovverket (12). Om det i praksis er blitt bedre, er fortsatt svært usikkert. Vi kan glede oss over at studien til Førde \& Aasland indikerer en positiv utvikling (2), men som forfatterne selv skriver vil en supplerende kvalitativ studie kunne gi bedre og sikrere svar. Uansett er det viktig å følge utviklingen over tid. Slik kan man få viktig informasjon om hvordan legerollen utvikler seg.

\section{Ivar Thomsen}

ivar.thomsen@lyse.net

Ivar Thomsen (f. 1951) er spesialist i allmennmedisin og fastlege ved Forus legesenter.

Forfatter har fylt ut ICMJE-skjemaet og oppgir ingen interessekonflikter.

\section{Litteratur}

1. Føllesdal A. Bør prioritering av helsetiltak baseres på pliktetikk eller nytteetikk? Tidsskr Nor Lægeforen 2003; 123: 2897-8

2. Førde R, Aasland OG. Moralsk stress og faglig ytringsfrihet blant leger. Tidsskr Nor Legeforen 2013; 133: 1310-4.

3. Andersen BM. Fusjon eller fiasko ved Oslo universitetssykehus? Dagbladet 31.5.2012. www.dagbladet.no/2012/05/31/kultur/debatt/helse/sykehus/fusjon/ 21857113/ (11.6.2013).

4. Haug C. Faremelding: Understrømmer. Tidsskr Nor Legeforen 2010; 130: 1805

5. Haug C. Makten i uklare formuleringer. Tidsskr Nor Legeforen 2010; 130: 1701

6. Grønli H, Eriksen KA. Ansatte tør ikke si hva de mener. NRK Nyheter 20.12.2011. www.nrk.no/nyheter/norge/1.7922758 (29.4.2012).

7. Storvik AG. - Tør ikke være tillitsvalgte. Dagens Medisin 18.10.2012 www.dagensmedisin.no/nyheter/--tor-ikke-vare-tillitsvalgte/ (11.6.2013).

8. Helse og omsorgsdepartementet. Høringer. Revidert fastlegeforskrift. www.regjeringen.no/nb/dep/hod/dok/hoeringer/hoeringsdok/2011/ revidert-fastlegeforskrift.html?id=667714 (11.6.2013)

. Fastlegeaksjonen. www.fastlegeaksjonen.no/ (11.6.2013)

10. Helsetjenesteaksjonen. www.helsetjenesteaksjonen.no/ (11.6.2013)

11. Førde R. Frå engasjert fagperson - til lydig funksjonær? Dagens Medisin 18.9.2012. www.dagensmedisin.no/debatt/fra-engasjert-fagperson---til-lydigfunksjonar/ (11.6.2013)

12. LOV 2005-06-17 nr. 62. Lov om arbeidsmiljø, arbeidstid og stillingsvern mv. www. lovdata.no/all/hl-20050617-062.html (11.6.2013). 